\title{
Aphotic $\mathbf{N}_{2}$ fixation along an oligotrophic to ultraoligotrophic transect in the western tropical South Pacific Ocean
}

\author{
Mar Benavides ${ }^{1,2}$, Katyanne M. Shoemaker ${ }^{3}$, Pia H. Moisander ${ }^{3}$, Jutta Niggemann ${ }^{4}$, Thorsten Dittmar ${ }^{4}$, \\ Solange Duhamel $^{5}$, Olivier Grosso ${ }^{6}$, Mireille Pujo-Pay ${ }^{7}$, Sandra Hélias-Nunige $^{6}$, Alain Fumenia ${ }^{1}$, and Sophie Bonnet ${ }^{1}$ \\ ${ }^{1}$ Aix Marseille Université, CNRS/INSU, Université de Toulon, IRD, Mediterranean Institute of Oceanography (MIO) \\ UM 110, 98848 Nouméa, New Caledonia \\ ${ }^{2}$ Marine Biology Section, Department of Biology, University of Copenhagen, 3000 Helsingør, Denmark \\ ${ }^{3}$ Department of Biology, University of Massachusetts Dartmouth, 285 Old Westport Road, \\ North Dartmouth, MA 02747, USA \\ ${ }^{4}$ Research Group for Marine Geochemistry (MPI-ICBM Bridging Group), Institute for Chemistry and Biology of the Marine \\ Environment University of Oldenburg, Carl-von-Ossietzky-Strasse 9-11, 26129 Oldenburg, Germany \\ ${ }^{5}$ Lamont-Doherty Earth Observatory, Division of Biology and Paleo Environment, Columbia University, P.O. Box 1000, 61 \\ Route 9W, Palisades, NJ 10964, USA \\ ${ }^{6}$ Aix Marseille Université, CNRS/INSU, Université de Toulon, IRD, Mediterranean Institute of Oceanography (MIO) \\ UM 110, 13288 Marseille, France \\ ${ }^{7}$ Laboratoire d'Océanographie Microbienne - UMR 7321, CNRS - Sorbonne Universités, UPMC Univ Paris 06, \\ Observatoire Océanologique, 66650 Banyuls-sur-mer, France
}

Correspondence: Mar Benavides (mar.benavides@bio.ku.dk)

Received: 15 December 2017 - Discussion started: 5 January 2018

Revised: 29 March 2018 - Accepted: 9 April 2018 - Published: 22 May 2018

\begin{abstract}
The western tropical South Pacific (WTSP) Ocean has been recognized as a global hot spot of dinitrogen $\left(\mathrm{N}_{2}\right)$ fixation. Here, as in other marine environments across the oceans, $\mathrm{N}_{2}$ fixation studies have focused on the sunlit layer. However, studies have confirmed the importance of aphotic $\mathrm{N}_{2}$ fixation activity, although until now only one had been performed in the WTSP. In order to increase our knowledge of aphotic $\mathrm{N}_{2}$ fixation in the WTSP, we measured $\mathrm{N}_{2}$ fixation rates and identified diazotrophic phylotypes in the mesopelagic layer along a transect spanning from New Caledonia to French Polynesia. Because non-cyanobacterial diazotrophs presumably need external dissolved organic matter (DOM) sources for their nutrition, we also identified DOM compounds using Fourier transform ion cyclotron resonance mass spectrometry (FTICRMS) with the aim of searching for relationships between the composition of DOM and non-cyanobacterial $\mathrm{N}_{2}$ fixation in the aphotic ocean. $\mathrm{N}_{2}$ fixation rates were low (average $0.63 \pm 0.07 \mathrm{nmol} \mathrm{N} \mathrm{L}^{-1} \mathrm{~d}^{-1}$ ) but consistently detected across all depths and stations, representing $\sim 6-88 \%$ of
\end{abstract}

photic $\mathrm{N}_{2}$ fixation. $\mathrm{N}_{2}$ fixation rates were not significantly correlated with DOM compounds. The analysis of nifH gene amplicons revealed a wide diversity of non-cyanobacterial diazotrophs, mostly matching clusters 1 and 3. Interestingly, a distinct phylotype from the major nifH subcluster $1 \mathrm{G}$ dominated at $650 \mathrm{dbar}$, coinciding with the oxygenated Subantarctic Mode Water (SAMW). This consistent pattern suggests that the distribution of aphotic diazotroph communities is to some extent controlled by water mass structure. While the data available are still too scarce to elucidate the distribution and controls of mesopelagic non-cyanobacterial diazotrophs in the WTSP, their prevalence in the mesopelagic layer and the consistent detection of active $\mathrm{N}_{2}$ fixation activity at all depths sampled during our study suggest that aphotic $\mathrm{N}_{2}$ fixation may contribute significantly to fixed nitrogen inputs in this area and/or areas downstream of water mass circulation. 


\section{Introduction}

Pelagic $\mathrm{N}_{2}$ fixation is considered the greatest input of fixed nitrogen to the oceans, adding up to $\sim 100-107 \mathrm{Tg} \mathrm{N}$ per year (Galloway et al., 2004; Codispoti, 2007; Gruber and Galloway, 2008; Jickells et al., 2017). In the sunlit layer of the warm oligotrophic tropical and subtropical oceans, cyanobacterial diazotrophs such as Trichodesmium, UCYN$\mathrm{B}$ and diatom-diazotroph associations (DDAs) dominate fixed nitrogen inputs via $\mathrm{N}_{2}$ fixation (Zehr, 2011). In colder and less oligotrophic waters at higher latitudes, other diazotrophs including UCYN-A and non-cyanobacterial groups may be more competitive (Moisander et al., 2010, 2014; Bonnet et al., 2015; Langlois et al., 2015), considerably expanding the latitudinal range over which $\mathrm{N}_{2}$ fixation is considered significant in predictive biogeochemical models. In the past decade, several studies have retrieved nifH sequences from the dark ocean, some also accompanied by low $\mathrm{N}_{2}$ fixation rates (Hamersley et al., 2011; Bonnet et al., 2013; Rahav et al., 2013). Due to the immense volume of the dark ocean, aphotic $\mathrm{N}_{2}$ fixation could influence the global nitrogen budget substantially. However, the number of published aphotic $\mathrm{N}_{2}$ fixation rates is scant and our understanding of the metabolism and ecology of aphotic diazotrophs is still limited, hindering our ability to evaluate their impact on global fixed nitrogen inputs (Moisander et al., 2017).

Non-cyanobacterial nifH sequences fall into four established nifH gene clusters (Chien and Zinder, 1996), are the most numerous in nifH gene databases (Riemann et al., 2010) and are spread throughout the global ocean (Farnelid et al., 2011; Langlois et al., 2015). As discussed in Bombar et al. (2016), the growth and activity of non-cyanobacterial diazotrophs may be controlled by (i) the presence of oxygen because oxygen destroys the nitrogenase enzyme, (ii) the availability of fixed nitrogen because $\mathrm{N}_{2}$ fixation becomes too energetically expensive when reduced nitrogen forms are readily available in the environment and (iii) the availability of energy because non-cyanobacterial diazotrophs may not be able to photosynthesize and thus rely on external fixed carbon sources. However, aphotic diazotrophic activity has been found both in oxygen-deficient regions such as the oxygen minimum zone of the eastern tropical South Pacific (Bonnet et al., 2013; Loescher et al., 2014) and the fully oxygenated mesopelagic waters in the Mediterranean Sea (Rahav et al., 2013; Benavides et al., 2016). Moreover, while fixed nitrogen availability should theoretically shut down $\mathrm{N}_{2}$ fixation, significant $\mathrm{N}_{2}$ fixation rates have been measured in the nitrate-rich mesopelagic waters of the western tropical South Pacific (WTSP) (Benavides et al., 2015). Finally, energy is likely made available to heterotrophic non-cyanobacterial diazotrophs through labile dissolved organic matter (DOM). Aphotic $\mathrm{N}_{2}$ fixation rates have been related to the presence of relatively labile DOM compounds such as transparent exopolymeric particles (TEP) in the WTSP (Benavides et al., 2015) or peptides and unsaturated aliphatics in the Mediter- ranean Sea (Benavides et al., 2016). The addition of small labile DOM molecules such as carbohydrates or amino acids has been shown to enhance aphotic $\mathrm{N}_{2}$ fixation in various environments (Bonnet et al., 2013; Rahav et al., 2013; Loescher et al., 2014; Benavides et al., 2015). However, some photic non-cyanobacterial diazotrophs also bear genes for the degradation of refractory DOM compounds (e.g., aromatic hydrocarbons; Bentzon-Tilia et al., 2015). It is thus reasonable to expect that aphotic non-cyanobacterial diazotrophs may be able to exploit diverse DOM sources. Unfortunately, the current lack of genome information from non-cyanobacterial aphotic diazotrophs does not allow us to assess how they are affected by DOM composition and lability.

The WTSP has been recently recognized as a global hot spot of photic $\mathrm{N}_{2}$ fixation, harboring among the highest $\mathrm{N}_{2}$ fixation rates ever recorded $\left(\sim 600 \mu \mathrm{mol} \mathrm{N} \mathrm{m}{ }^{-2} \mathrm{~d}^{-1}\right.$; Bonnet et al., 2017), mostly attributed to Trichodesmium and UCYN-B (Bonnet et al., 2009, 2015; Berthelot et al., 2017; Stenegren et al., 2018). To the eastern border of this region, the ultraoligotrophic South Pacific Gyre (GY) has low photic $\mathrm{N}_{2}$ fixation rates (Raimbault and Garcia, 2008), which have been mainly attributed to small unicellular diazotrophs such as UCYN-A and Gammaproteobacteria (Bonnet et al., 2009; Halm et al., 2011; Stenegren et al., 2018). Despite its potentially immense implications in global fixed nitrogen inputs, the aphotic $\mathrm{N}_{2}$ fixation potential of the WTSP remains mostly unexplored (Benavides et al., 2015). Here we quantify $\mathrm{N}_{2}$ fixation and describe the communities based on the nifH gene in the mesopelagic layer along a $\sim 5000 \mathrm{~km}$ transect in the WTSP spanning from oligotrophic to ultraoligotrophic conditions (Moutin et al., 2017).

\section{Materials and methods}

\subsection{Hydrography, nutrients, chlorophyll $a$ and dissolved organic carbon}

The OUTPACE cruise (Oligotrophy to Ultraoligotrophy South Pacific Experiment; https://doi.org/10.17600/15000900) took place onboard the R/V L'Atalante from 20 February to 2 April 2015 (i.e., during austral summer), sailing westwards from New Caledonia to French Polynesia (see Fig. 2 in Moutin et al., 2017). Temperature, salinity, chlorophyll fluorescence and oxygen data were obtained using an SBE 9 plus CTD mounted on a General Oceanics rosette frame fitted with 24-12 L Niskin bottles.

Seawater samples were collected with Niskin bottles mounted on a rosette frame at 15 short-duration $(\mathrm{SD}, 8 \mathrm{~h})$ and 3 long-duration (LD, 7 days) stations (Moutin et al., 2017). Samples for the determination of the inorganic nutrients nitrate $\left(\mathrm{NO}_{3}^{-}\right)$, nitrite $\left(\mathrm{NO}_{2}^{-}\right)$and phosphate $\left(\mathrm{PO}_{4}^{3-}\right)$ were collected in $20 \mathrm{~mL}$ acid-washed polyethylene flasks, poisoned with $1 \%$ mercury chloride and analyzed onshore using an AA3 Bran + Luebbe autoanalyzer. The detection 
limit for both $\mathrm{NO}_{3}^{-}$and $\mathrm{PO}_{4}^{3-}$ was $0.05 \mu \mathrm{M}$. Samples for the determination of dissolved organic carbon (DOC) were collected in combusted glass bottles and immediately filtered through two mounted precombusted $\left(4 \mathrm{~h}, 450^{\circ} \mathrm{C}\right) 25 \mathrm{~mm}$ GF/F filters $(0.7 \mu \mathrm{m}$, Whatman $)$ using a custom-made allglass-Teflon filtration syringe system. Filtered seawater was directly collected in precombusted glass ampoules and acidified to $\mathrm{pH} 2$ with orthophosphoric acid. Ampoules were immediately sealed and stored cold $\left(4^{\circ} \mathrm{C}\right)$ and in the dark until analyses by high-temperature catalytic oxidation on a Shimadzu TOC-L analyzer according to Sohrin and Sempéré (2005). Typical analytical precision is $\pm 0.1-0.5$ (SD) or $0.2-0.5 \%$ (coefficient of variation, CV). Consensus reference materials were injected every 12 to 17 samples to control for stable operating conditions. Chlorophyll $a$ (Chl $a$ ) concentrations were determined from $500 \mathrm{~mL}$ samples filtered through GF/F filters. Chl $a$ was extracted in methanol and measured by fluorometry (Herbland et al., 1985).

\subsection{DOM analysis}

Samples for ultra-high-resolution mass spectrometry analyses were collected in acid-cleaned $2 \mathrm{~L}$ transparent polycarbonate bottles and extracted (solid-phase) via Agilent PPL cartridges as described in Dittmar et al. (2008). After extraction, the cartridges were rinsed with acidified ultrapure water and frozen at $-20^{\circ} \mathrm{C}$. Subsequently, the samples were dried by flushing with high-purity $\mathrm{N}_{2}$ and eluted with $6 \mathrm{~mL}$ of methanol. The efficiency of the extraction was $47.3 \pm 3.9 \%$ on a carbon basis. Methanol extracts were molecularly characterized on a 15 Tesla Fourier transform ion cyclotron resonance mass spectrometer (Solarix FTICRMS) using an electrospray ionization source in negative mode (Bruker Apollo II). Molecular formulae were ascribed to the detected masses as outlined in Seidel et al. (2014). The aromaticity and unsaturation degree of each compound were evaluated according to its molecular formula and were presented as the modified aromaticity index (AI-mod) and double bond equivalents (DBE), respectively (Koch and Dittmar, 2006). In addition, we ascribed the identified molecular formulae to compound groups according to established molar ratios, AI-mod, DBE and heteroatom contents (Seidel et al., 2014). To reveal compositional differences among samples, we performed a principal coordinate analysis (PCoA) on Bray-Curtis distance matrices, including all detected molecular formulae and their respective relative FTICRMS signal intensities. The PCoA scores were correlated against all hydrographic and biological variables measured in our study.

\section{$2.3 \quad \mathrm{~N}_{2}$ fixation rates}

Seawater was sampled at each SD station from 200, 500, 650 and $800 \mathrm{dbar}$ in quadruplicate $4.3 \mathrm{~L}$ transparent polycarbonate bottles covered with black cloth. Each bottle was spiked with $6 \mathrm{~mL}$ of ${ }^{15} \mathrm{~N}_{2}$ gas (98.9\% Euriso-top), inverted
20-30 times and incubated in the dark at $8^{\circ} \mathrm{C}$ in temperatureregulated incubators onboard. After $24 \mathrm{~h}$ of incubation, each pair of bottles was filtered onto two separate precombusted GF/F filters (two bottles concentrated per filter) and stored at $-20^{\circ} \mathrm{C}$ until analyzed with an Integra2 analyzer calibrated every 10 samples using reference material (IAEA-N1). To obtain accurate $\mathrm{N}_{2}$ fixation rates we (1) measured the $\delta^{15} \mathrm{~N}$ of background $\mathrm{N}_{2}$ in the incubation on each incubation bottle by membrane inlet mass spectrometry analyses (MIMS; Kana et al., 1994) with obtained values of $7.548 \pm 0.557$ at $\%$ (Bonnet et al., 2018), (2) collected time zero samples in duplicate at each depth and station to determine the natural $\delta^{15} \mathrm{~N}$ of ambient particulate nitrogen (PN) and (3) subtracted blank GF/F PN values from our results. $\mathrm{N}_{2}$ fixation rates were calculated with the equations of Montoya et al. (1996). Considering the PN linearity limit of the mass spectrometer $(2.32 \mu \mathrm{g} \mathrm{N}), 3$ times the standard deviation of time zero values (natural $\delta^{15} \mathrm{~N}$ of $\mathrm{PN}$ ), and our usual filtration volume $(8.6 \mathrm{~L})$ and incubation time $(24 \mathrm{~h})$, our volumetric $\mathrm{N}_{2}$ fixation rate detection limit was $0.027 \mathrm{nmol} \mathrm{N} \mathrm{L}^{-1} \mathrm{~d}^{-1}$. The minimum quantifiable rate calculated using standard propagation of errors via the observed variability between replicate samples was $0.006 \mathrm{nmol} \mathrm{N} \mathrm{L}^{-1} \mathrm{~d}^{-1}$.

\subsection{Flow cytometry}

Samples for cell enumeration were collected at the same stations and depths as samples for the quantification of $\mathrm{N}_{2}$ fixation rates. Samples of $1.8 \mathrm{~mL}$ were fixed $(0.25 \%$ electron microscopy grade paraformaldehyde, $w / v$ ) for 10$15 \mathrm{~min}$ at room temperature in the dark, flash-frozen in liquid nitrogen and stored at $-80^{\circ} \mathrm{C}$ for later analysis using a BD Influx flow cytometer (BD Biosciences, San Jose, CA, USA). Samples were thawed at room temperature in the dark, and reference beads (Fluoresbrite, YG, $1 \mu \mathrm{m}$ ) were added to each sample. The non-pigmented bacterioplankton (hereafter bacteria) were discriminated in a sample aliquot stained with SYBR Green I DNA dye (1:10000 final). Because the Prochlorococcus population cannot be uniquely distinguished in the SYBR stained samples in the upper water column, bacteria were determined as the difference between the total cell numbers of the SYBR stained sample and Prochlorococcus enumerated in unstained samples. Particles were excited at $488 \mathrm{~nm}$ (plus $457 \mathrm{~nm}$ for unstained samples), and forward scatter (FSC; $<15^{\circ}$ ), green fluorescence $(530 / 40 \mathrm{~nm})$, orange fluorescence $(580 / 30 \mathrm{~nm})$ and red fluorescence $(>650 \mathrm{~nm})$ emissions were measured. Bacteria were discriminated based on their green fluorescence and FSC characteristics. Cytograms were analyzed using FCS Express 6 Flow Cytometry Software (De Novo Software, CA, US). 


\subsection{DNA extraction, sequencing and sequence analysis}

Samples for DNA extraction were collected in duplicate in $4.3 \mathrm{~L}$ polycarbonate bottles and the total volume was filtered immediately through $0.2 \mu \mathrm{m}$ Supor filters (Pall Gelman). The filters were stored in bead beater tubes and kept at $-80^{\circ} \mathrm{C}$ until analysis. Samples were collected from four depths (200, 500,650 and $850 \mathrm{dbar}$ ) at all SD stations, with the exception of station SD5 where seawater for DNA analyses was only collected at $500 \mathrm{dbar}$ and station SD14 where only 200 and $800 \mathrm{dbar}$ were analyzed. DNA was extracted using the Qiagen Plant kit, with additional freeze-thaw, bead beating and Proteinase K steps for sample preparation before the kit purification, and elution to $100 \mu \mathrm{L}$ as previously described (Moisander et al., 2008). PCR was conducted using degenerate, nested nifH primers (Zehr et al., 2001) and the secondround primers modified for Illumina library preparation using a Bio-Rad C1000 thermocycler. The PCR mix was composed of $2.5 \mu \mathrm{L}$ of 10X Platinum Taq PCR buffer (Thermo Fisher), $\mathrm{MgCl}$ (2.5 mM final), dNTPs ( $0.2 \mathrm{mM}$ final), primers ( $1 \mu \mathrm{M}$ final), $0.11 \mu \mathrm{L}$ Platinum Taq and $4 \mu \mathrm{L}$ of DNA extract ( $1 \mu \mathrm{L}$ on second round) adjusted to $25 \mu \mathrm{L}$ total volume with nuclease free water. To alleviate PCR biases, PCR was conducted in triplicate in each round of reactions for which firstround triplicate reaction products were pooled, then $1 \mu \mathrm{L}$ was used as a template in triplicate reactions on the second round. A negative PCR control with water as a template was included and treated in parallel with samples through all the subsequent steps. Subsamples of the amplification products were checked via $1.2 \%$ TAE gel electrophoresis. The second-round products showing a band of the expected size were pooled and purified using a magnetic bead protocol (Ampure, Beckman Coulter). The purified products were barcoded for Illumina (San Diego, CA, USA) MiSeq sequencing with Nextera indexes using the manufacturer protocol. The indexed products were purified again with magnetic beads, then quantified with a plate reader (Molecular Devices, Sunnyvale, CA, USA) using PicoGreen (Thermo Fisher). The indexed samples were adjusted to equal concentrations and pooled for multiplexing during sequencing. The pooled sample was shipped to the Tufts University sequencing center (Boston, MA, USA) for paired end sequencing $(2 \times 300 \mathrm{bp})$. The quality of the pooled sample and select individual samples was checked with a bioanalyzer before the run. The resulting sequences were paired within mothur (Schloss et al., 2009), and reads containing ambiguities or more than eight homopolymers were discarded. The sequences were assigned to OTUs (at $97 \%$ cutoff) using the UCLUST denovo picking method (Edgar, 2010) implemented in MacQIIME v1.9.1 (Caporaso et al., 2010). Low-abundance OTUs consisting of fewer than 15 sequences across all samples were discarded from further processing. A representative sequence of each OTU was extracted from the data and quality processed in ARB (Ludwig et al., 2004), removing sequences that did not conceptually translate or were otherwise of poor quality. These OTUs were removed from further analysis. Remaining sequences were aligned based on protein alignment of the nifH fragments in a public nifH database (https://www.jzehrlab.com/nifh, last access: 15 September 2017). Aligned protein sequences were assigned to nifH clusters using a decision tree statistical model, CART (Frank et al., 2016). The sequence data were normalized to the proportion of total reads in each sample. Total relative abundances of sequences that fell in major nifH clusters were used to create a heatmap within R Studio using the "vegan" statistical package (Oksanen et al., 2015). Sequences were further classified through a locally run blastp using the nifH database as a reference (April 2015 database update). A neighbor-joining tree was built in ARB with the 100 most abundant OTUs across all samples.

\section{Results}

\subsection{Hydrography, nutrients, DOC and bacterial abundance}

Sections of hydrographic variables (temperature, salinity) are shown in Fig. 3a-b in Moutin et al. (2017), and nutrient concentrations $\left(\mathrm{NO}_{x}-\right.$ i.e., $\mathrm{NO}_{3}^{-}+\mathrm{NO}_{2}^{-}-$and $\left.\mathrm{PO}_{4}^{3-}\right)$ are shown in Fig. 5a-b in Fumenia et al. (2018). DOC and bacterial abundance are shown in Fig. S1 in the Supplement. All variables show a clear divide between the Melanesian Archipelago waters (MA; stations SD1 to SD12) and the South Pacific Gyre (GY; eastwards of SD12; Moutin et al., $2017)$. Lower temperatures and salinity values $\left(<8^{\circ} \mathrm{C}\right.$ and $\sim 35$, respectively) were measured below 450 to $600 \mathrm{dbar}$ in the MA, while they were detected at shallower depths eastwards in the GY (Fig. 3a-b in Moutin et al., 2017). Nutrient concentrations were high throughout the mesopelagic zone west of New Caledonia $(>30 \mu \mathrm{M} \mathrm{NO} x$ and $>2 \mu \mathrm{M}$ $\mathrm{PO}_{4}^{3-}$; Fig. 3a-b in Fumenia et al., 2018). Sailing eastwards, $\mathrm{NO}_{x}$ in the MA region was $<5 \mu \mathrm{M}$ between 150 and $250 \mathrm{dbar}$, with high concentrations $>30 \mu \mathrm{M}$ being detected at $\sim 680$ dbar. Such high $\mathrm{NO}_{x}$ concentrations were detected at shallower depths (500 to $600 \mathrm{dbar}$ ) in the GY. $\mathrm{PO}_{4}^{3-}$ followed a similar pattern, with the highest concentrations detected at depths $>500 \mathrm{dbar}$ reaching $2.5 \mu \mathrm{M}$ (Fig. 3a-b in Fumenia et al., 2018). DOC concentrations presented a pattern opposite to that of inorganic nutrients, with $<300$ dbar presenting concentrations of 50-60 $\mu \mathrm{M}$, lowering to $<40 \mu \mathrm{M}$ below $600 \mathrm{dbar}$ (Fig. S1a). Bacterial abundance

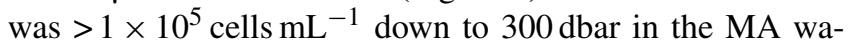
ters, while its numbers decreased abruptly in the GY, especially east of SD12 (Fig. S1b)

\subsection{High-resolution analysis of DOM (FTICRMS)}

FTICRMS analysis of DOM yielded $\sim 13500$ molecular formulae in each sample, covering a mass range between 150 and $1000 \mathrm{Da}$ (measured in daltons). Each molecular formula 


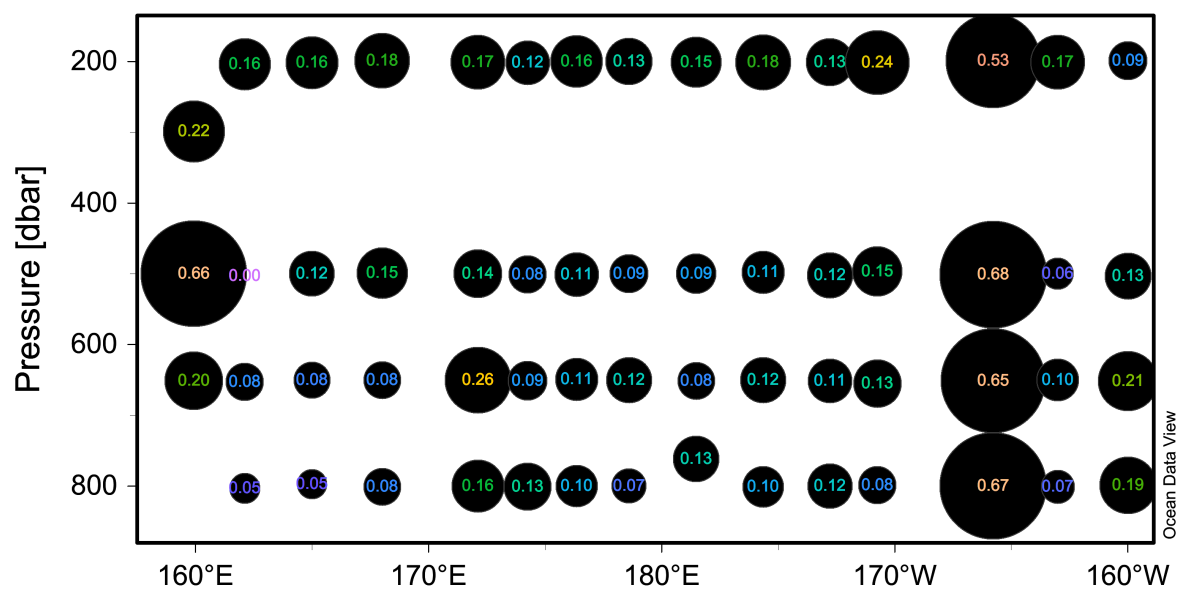

Figure 1. Longitudinal section of $\mathrm{N}_{2}$ fixation (nmol $\mathrm{N} \mathrm{L}^{-1} \mathrm{~d}^{-1}$ ) rates displayed as numbers overlying sized circles. For reference, the station numbers are displayed on top of the panel.

was assigned to a given compound group as described in Seidel et al. (2014). According to this grouping, $4-31 \%$ of all compounds detected were oxygen-poor $(\mathrm{O} / \mathrm{C}<0.5)$ unsaturated aliphatics, $16 \%$ were oxygen-rich $(\mathrm{O} / \mathrm{C}>0.5)$ unsaturated aliphatics and $13 \%$ were polyphenols, while saturated fatty acids, sugars and peptides represented $<3 \%$. Compounds usually regarded as labile DOM (peptides, sugars and saturated fatty acids) were relatively more abundant in the MA (data not shown).

\subsection{Aphotic $\mathrm{N}_{2}$ fixation rates}

Aphotic $\mathrm{N}_{2}$ fixation rates were measurable at all stations and depths and ranged between 0.05 and $0.68 \mathrm{nmol} \mathrm{NL}^{-1} \mathrm{~d}^{-1}$ (Fig. 1). These rates did not seem to follow any longitudinal or vertical pattern. However, the rates observed at station SD13 (where a massive surface concentration of chlorophyll was observed; de Verneil et al., 2017) were on average $\sim 5$-fold higher than at the other stations (average $0.63 \pm 0.07 \mathrm{nmol} \mathrm{N} \mathrm{L}^{-1} \mathrm{~d}^{-1}$ ).

\subsection{Diazotroph community composition}

There were 3317-146864 (mean $=88867, \mathrm{SD}=42574)$ sequences per sample after pairing and the QA / QC steps. The negative control resulted in only eight reads belonging to six OTUs. These sequences are likely a result of misbinning at the time of sequencing, and therefore the negative control was removed from downstream analysis. Shannon diversity at the $97 \%$ OTU level was not significantly affected by either depth or station (one-way ANOVA $p>0.05$ ). The majority of nifH sequences fell to clusters 1 and 3, although clusters 2 and 4 were represented in the transect at low relative abundances (Fig. 2). Within cluster 1, subcluster 1G, which contains Gammaproteobacteria, accounted for over half of the total sequences $(56 \%, \mathrm{SD}=38 \%)$. With a few excep- tions, in samples with lower proportions of $1 \mathrm{G}$, subcluster $3 \mathrm{~S}$ was the most abundant group. Cluster $3 \mathrm{~S}$ had high relative abundances at station SD10 and in the 200 and $500 \mathrm{dbar}$ depths of stations SD2 and SD12, as well as at $200 \mathrm{dbar}$ at station SD13. The cyanobacterial subcluster 1B was observed at a very low relative abundance throughout all stations and depths (average $0.5 \%$ of total community) and included Trichodesmium, UCYN-A and Richelia. Consistent variations in community composition among depths and stations were not detected via cluster-based analysis; however, patterns emerged when observing data at the OTU level in abundant clusters (Fig. 3). In subcluster 1G, reads most closely matching an unclassified bacterium from the tropical North Atlantic (Unc12217, $E$ value $=2.82 \times 10^{-70}$; Table 1 , Fig. 4) in the nifH database dominated the communities in the $650 \mathrm{dbar}$ depth, and this phylotype was found only at minor proportions in other depths. This phylotype had an approximately $83 \%$ amino acid identity with Agrobacterium tumefaciens (Table 1, Fig. 4). This phylotype was present at high proportions across all other $650 \mathrm{dbar}$ samples except at station SD2, the westernmost station. Although identified as "Other $1 G$ " in Fig. 3, this trend was also true for several other groups present only at the $650 \mathrm{dbar}$ depth (best matches with database sequences Unc12243, Unc12270 and UncPr491; Table 1). An additional group was found only at 650 dbar in the easternmost stations (SD10-SD13), closely matching a sequence from the Amazon River (UncM2163, $E$ value $=4.22 \times 10^{-74}$; Table 1). Within the nifH cluster 3 , subcluster $3 \mathrm{~S}$ was the most widespread and abundant, with representation from three groups in the reference database: Unc12045, UncB2403 and UncMa132. Sequences with the best matches with Unc12045 (Genbank ID: ADV51583; Turk et al., 2011) and UncB2403 (AAP48957; Steward et al., 2004) were present at stations SD2, SD4, SD10 and SD12, but had the highest relative abundance at station SD10, 


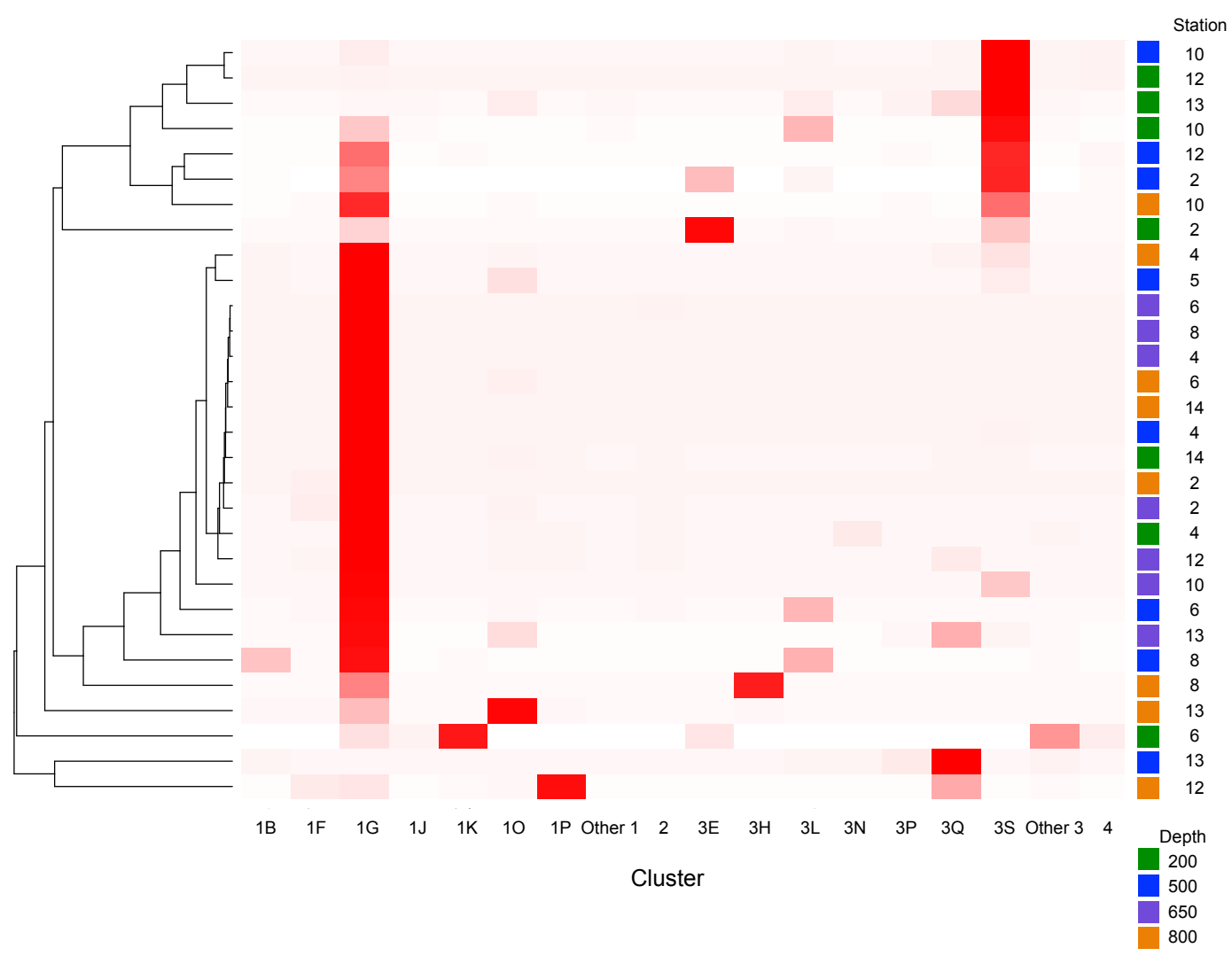

Figure 2. Heatmap of nifH clusters and subclusters across the stations. The Bray-Curtis distances were used to build the dendrogram on the left. Distances were calculated with relative abundances of sequences by subcluster. Subclusters within clusters 1 and 3 that had low relative abundances throughout all samples have been grouped as "other".

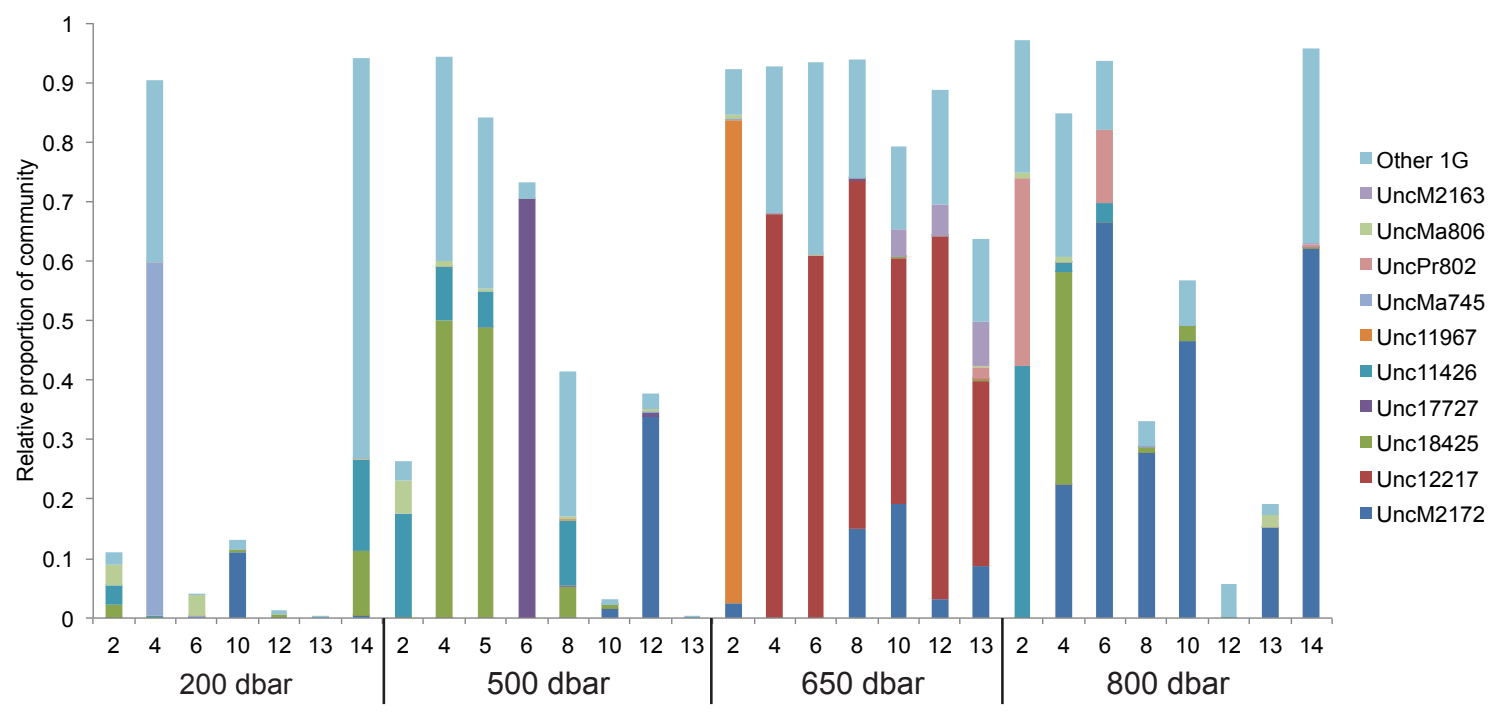

Figure 3. Relative abundance of subcluster $1 \mathrm{G}$ over pressure levels (depths) and stations. Each bar represents the relative abundance of subcluster $1 \mathrm{G}$ in the total community for each sample. Samples are arranged by station within each of the pressure levels sampled. Blastp was used to assign OTUs to a top hit in the nifH reference database. The major sequence types in the nifH database found in subcluster $1 \mathrm{G}$ are shown with different colors. 


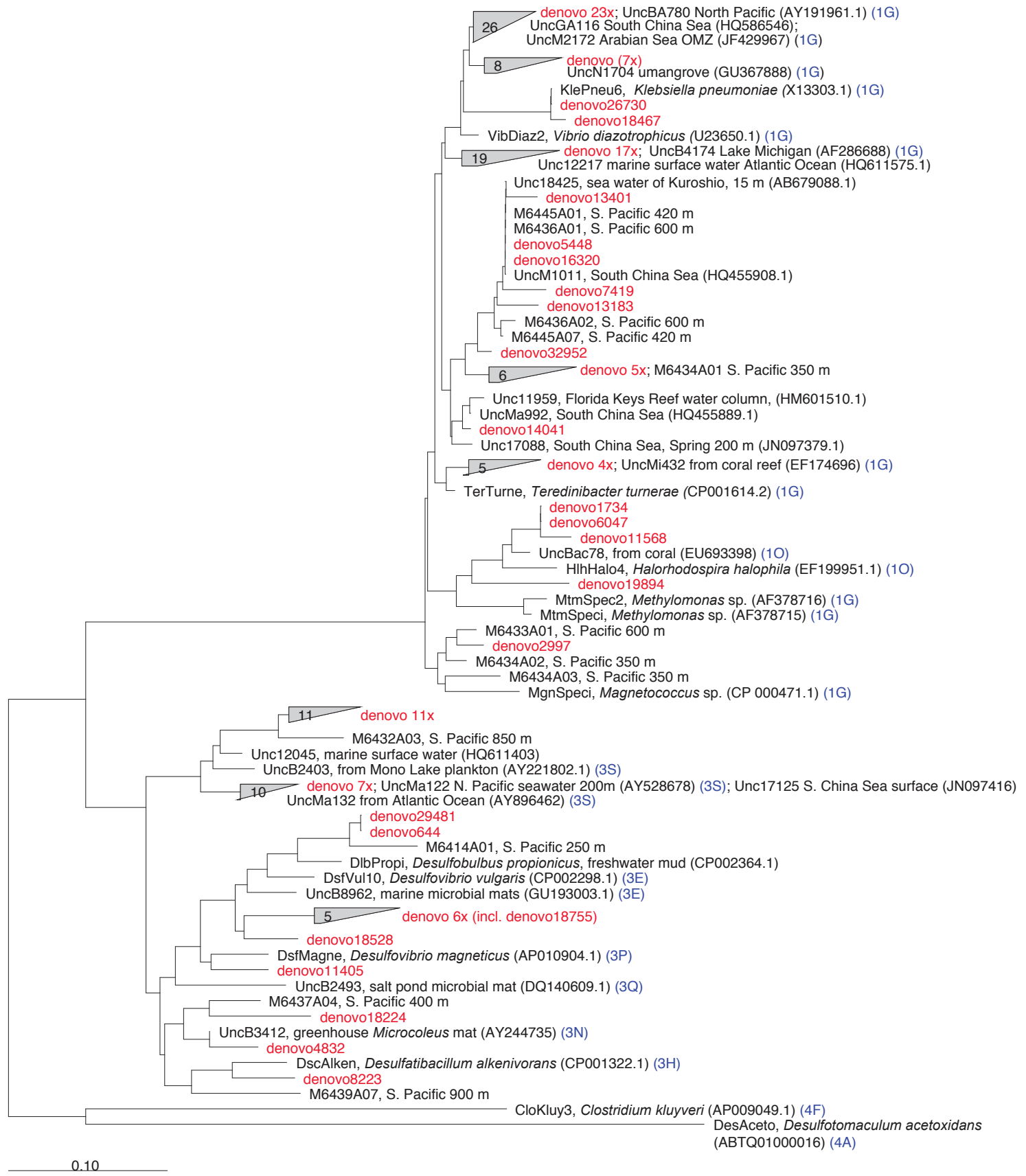

Figure 4. The nifH amino acid neighbor-joining tree with the 100 most abundant OTUs from this study. Sequences beginning with "denovo", shown in red, are randomly chosen representative sequences from these OTUs (OTUs binned at $97 \%$ identity). The clusters in the tree are grouped at an approximately $>95 \%$ sequence identity. The tree includes reference sequences (if uncultivated, the names of these sequences start with "Unc"). The reference sequences are shown with accession numbers from the nifH database and with the cluster identifier shown in blue if indicated in the nifH database. Additional sequences are included from a previous study in the South Pacific mesopelagic layers (Benavides et al., 2015); these clones are labeled with the original clone names M64XXAXX and depths. 
Table 1. Blastp identities to members of the $1 \mathrm{G}$ subcluster.

\begin{tabular}{|c|c|c|c|c|}
\hline nifH ID & $\begin{array}{l}\text { Accession } \\
\text { number }\end{array}$ & Study & $\begin{array}{l}\text { Location } \\
\text { reported }\end{array}$ & $\begin{array}{l}\text { Closest cultivated relative } \\
\text { (identity, } E \text { value) }\end{array}$ \\
\hline UncM2172 & ABV00657 & $\begin{array}{l}\text { Unpublished (Moisander and } \\
\text { Subramaniam et al.) }\end{array}$ & Gulf of Guinea & Vibrio diazotrophicus $(98 \%, 1 \mathrm{e}-71)$ \\
\hline Unc12217 & ADV51755 & Turk et al. (2011) & $\begin{array}{l}\text { Tropical eas- } \\
\text { tern N. Atlantic }\end{array}$ & Agrobacterium tumefaciens $(83 \%, 4 \mathrm{e}-55)$ \\
\hline Unc18425 & BAN66776 & Unpublished (Shiozaki et al.) & $\begin{array}{l}\text { Northern S. } \\
\text { China Sea }\end{array}$ & Pseudomonas stutzeri $(86 \%, 1 \mathrm{e}-64)$ \\
\hline Unc17727 & ABV00657 & $\begin{array}{l}\text { Unpublished (Moisander and } \\
\text { Subramaniam et al.) }\end{array}$ & Gulf of Guinea & Klebsiella pneumoniae $(100 \%, 4 \mathrm{e}-95)$ \\
\hline Unc11967 & ADV35118 & $\begin{array}{l}\text { Unpublished (Olson and } \\
\text { Lesser) }\end{array}$ & Florida Keys & Pseudanabaena cf. persicina $(97 \%, 3 \mathrm{e}-78)$ \\
\hline UncMa745 & ABX39720 & Moisander et al. (2008) & S. China Sea & Pseudomonas stutzeri $(96 \%, 1 \mathrm{e}-70)$ \\
\hline UncPr802 & AEA49463 & Fernandez et al. (2011) & $\begin{array}{l}\text { Eastern S. } \\
\text { Pacific }\end{array}$ & Vibrio natriegens $(96 \%, 3 \mathrm{e}-74)$ \\
\hline UncMa806 & AAY60084 & Langlois et al. (2005) & Atlantic Ocean & Agrobacterium tumefaciens $(96 \%, 1 \mathrm{e}-70)$ \\
\hline UncM2163 & ABF21183 & $\begin{array}{l}\text { Unpublished (Hewson and } \\
\text { Fuhrman) }\end{array}$ & Amazon River & Vibrio diazotrophicus $(81 \%, 6 \mathrm{e}-55)$ \\
\hline Unc12136 & ADV51674 & Turk et al. (2011) & $\begin{array}{l}\text { Tropical eas- } \\
\text { tern N. Atlantic }\end{array}$ & Agrobacterium tumefaciens $(96 \%, 2 \mathrm{e}-69)$ \\
\hline Unc12270 & ADV51808 & Turk et al. (2011) & $\begin{array}{l}\text { Tropical eas- } \\
\text { tern N. Atlantic }\end{array}$ & Vibrio diazotrophicus $(79 \%, 1 \mathrm{e}-52)$ \\
\hline UncMa747 & ABX39731 & Moisander et al. (2008) & S. China Sea & Pseudomonas stutzeri (84\%, 6e-60) \\
\hline Unc12551 & ADO20633 & Halm et al. (2011) & S. Pacific Gyre & Pseudanabaena cf. persicina $(95 \%, 2 \mathrm{e}-70)$ \\
\hline UncMa832 & ABD62932 & Unpublished (Foster et al.) & Atlantic Ocean & Pseudomonas stutzeri $(84 \%, 5 \mathrm{e}-60)$ \\
\hline Unc15356 & AER93057 & Unpublished (Lopez) & $\begin{array}{l}\text { Mexican oasis } \\
\text { system soil }\end{array}$ & Pseudanabaena cf. persicina $(95 \%, 1 \mathrm{e}-78)$ \\
\hline UncPr491 & AEA49150 & Fernandez et al. (2011) & $\begin{array}{l}\text { Eastern S. } \\
\text { Pacific }\end{array}$ & Pseudanabaena cf. persicina $(98 \%, 3 \mathrm{e}-76)$ \\
\hline Unc12243 & ADV51781 & Turk et al. (2011) & $\begin{array}{l}\text { Tropical eas- } \\
\text { tern N. Atlantic }\end{array}$ & Vibrio diazotrophicus $(80 \%, 2 \mathrm{e}-54)$ \\
\hline
\end{tabular}

$500 \mathrm{dbar}$ at station SD2, and the 200 and 500 dbar depths of station SD12. UncMa132 (AAS98182; unpublished) related groups were recovered from all stations at a low relative abundance, with the highest relative abundance in the 200 dbar samples from stations SD2, SD10, SD12 and SD13 as well as the 800 dbar samples from stations SD4 and SD10. These $3 \mathrm{~S}$ groups have no closely related cultivated isolates, with the closest similarity with Spirochaeta aurantia (74$78 \%$ similarity, AF325792). All of the top 100 most abundant OTUs fell in clusters 1 and 3 (Fig. 4). The majority fell in the cluster $1 \mathrm{G}$, with several additional phylotypes present in addition to the major ones discussed above. Several OTUs were closely related to previously described sequences from the South Pacific Ocean mesopelagic layers (Benavides et al., 2015). Magnetococcus sp., Methylomonas sp. and Teredinibacter turnerae were among the closest cultivated representatives to the cluster 1G OTUs recovered (Fig. 4). Among the OTUs that fell into cluster 3, Desulfovibrio spp. were the closest cultivated representatives in the NCBI database.

\section{5 $\quad \mathrm{N}_{2}$ fixation and diazotrophs related to in situ environmental parameters}

Bonferroni-corrected Spearman rank correlations showed that $\mathrm{N}_{2}$ fixation rates were only significantly correlated with temperature $(\rho=0.263, p=0.045)$, salinity $(\rho=0.284$, $p=0.029)$ and DOC concentrations $(\rho=0.269, p=0.042$; 


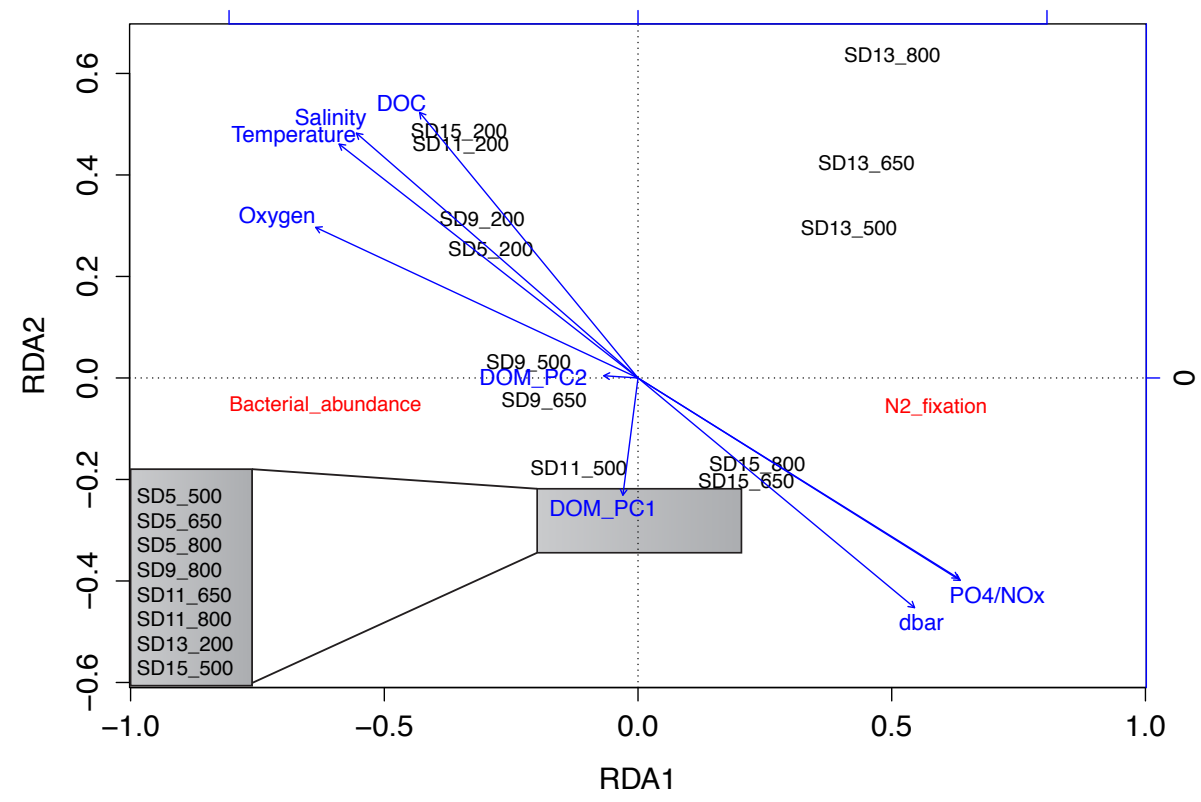

Figure 5. Redundancy analysis (RDA) ordination biplot showing the relationship between $\mathrm{N}_{2}$ fixation rates, bacterial abundance, depth, environmental variables (temperature, salinity and oxygen), dissolved organic matter (DOM) principal coordinates, dissolved organic carbon (DOC) and inorganic nutrient concentrations. The samples within the grey box were so similar to each other that their labels overlapped when plotted, so in the figure they are listed in a zoom-out box on the left bottom corner of the panel.

note that these hydrographic variables and DOC were intercorrelated; data not shown; Table S1 in the Supplement). A redundancy analysis (RDA; Fig. 5) including hydrographic variables, inorganic nutrients, DOC, bacterial abundance, $\mathrm{N}_{2}$ fixation rates and DOM PCoA scores indicated that $\mathrm{N}_{2}$ fixation rates were not related to DOM compositional variability (Table $\mathrm{S} 1$ ). $\mathrm{N}_{2}$ fixation rates from shallower depths such as those from $200 \mathrm{dbar}$ were significantly related to temperature, salinity, oxygen and DOC concentrations, while the first principal coordinate of DOM related to the majority of the samples. Stations SD13 and SD15 (easternmost part of the transect, within the GY) were partly related to depth and $\mathrm{NO}_{x}$ concentrations (samples from 650 and $800 \mathrm{dbar}$ ), while the rest of the samples of the profile appeared very distant in the RDA plot (Fig. 5).

\section{Discussion}

The aphotic $\mathrm{N}_{2}$ fixation activity measured in the WTSP was low (average $0.18 \pm 0.07 \mathrm{nmol} \mathrm{N} \mathrm{L}^{-1} \mathrm{~d}^{-1}$ ) but consistently detected across all depths and stations (Fig. 1), representing on average 13 and $51 \%$ of photic $\mathrm{N}_{2}$ fixation in the MA and GY waters, respectively (Bonnet et al., 2018), or 6-88\% of overall photic $\mathrm{N}_{2}$ fixation across the whole OUTPACE transect. It is pertinent to note that aphotic $\mathrm{N}_{2}$ fixation rates may be underestimated if a significant percentage of the non-cyanobacterial diazotroph population is smaller than $0.7 \mu \mathrm{m}$ (the nominal pore size of GF/F filters), as mea- sured $\mathrm{N}_{2}$ fixation rates in non-cyanobacteria-dominated environments have been reported to be significantly higher when smaller pore size filters are used (Bombar et al., 2018). Aphotic $\mathrm{N}_{2}$ fixation may contribute significantly to global fixed nitrogen inputs if widespread throughout the ocean's mesopelagic zone (or deeper). Unfortunately, our ability to assess this contribution remains hindered by the lack of specific $\mathrm{N}_{2}$ fixation methods and our poor understanding of the ecophysiology of non-cyanobacterial diazotrophs (Bombar et al., 2016; Moisander et al., 2017).

$\mathrm{N}_{2}$ fixation rates in aphotic environments correlate with different DOM compound groups in different regions (Benavides et al., 2015, 2016), and nifH gene expression varies among non-cyanobacterial diazotroph phylotypes when exposed to conditions presumed to enhance their $\mathrm{N}_{2}$ fixation activity (Severin et al., 2015). $\mathrm{N}_{2}$ fixation was detected as low rates across an oligotrophic-to-ultraoligotrophic transect in the WTSP. These rates were not significantly correlated with DOM compounds as identified by FTICRMS, although they were positively correlated with DOC concentrations. Noncyanobacterial diazotroph communities are usually highly diverse in aphotic marine waters (Hewson et al., 2007). If such phylogenetic diversity also entails a broad metabolic diversity and different affinities for DOM compounds, correlations between DOM and non-cyanobacterial diazotroph abundance, identity and/or $\mathrm{N}_{2}$ fixation activity will likely be blurred. Such ecophysiological heterogeneity may also be re- 
flected by the lack of longitudinal and vertical patterns in the $\mathrm{N}_{2}$ fixation rates observed along the transect (Fig. 1).

Some depth- and longitude-related patterns were observed within the potential diazotroph community, one of the major patterns being a distinct $A$. tumefaciens-related phylotype from the major nifH subcluster $1 \mathrm{G}$ dominating at the $650 \mathrm{dbar}$ depth. These sequences were unique from the $1 \mathrm{G}$ sequences found at other depths and, with the exception of station SD2, were found uniformly across stations. A potential driver for the depth variation seen at 650 dbar is the presence of the oxygenated Subantarctic Mode Water (SAMW) at this depth (Fumenia et al., 2018). The high concentration of oxygen in this water mass (190-220 $\mu \mathrm{mol} \mathrm{kg} \mathrm{g}^{-1}$ ) could potentially be linked to this change in diazotroph community to members that can withstand higher levels of oxygen. To our knowledge, this is the first study identifying a relationship between nifH community composition and large-scale oceanographic circulation patterns in mesopelagic depths. Unfortunately, the coverage of our samples throughout the mesopelagic zone was not enough to represent all the different water masses present and to identify patterns in $\mathrm{N}_{2}$ fixation activity or diversity of diazotrophs according to water mass distribution (see $T / S$ diagram in Fig. S2).

Members of the $1 \mathrm{G}$ subcluster include a variety of Gammaproteobacteria, and this group has previously been reported at high numbers in tropical surface waters including in the WTSP (Messer et al., 2017). In mesopelagic waters, transcripts from the $1 \mathrm{G}$ subcluster have been reported in an oxygen-deficient zone in the Arabian Sea at a depth of $175 \mathrm{~m}$ (Jayakumar et al., 2012), and genes have been reported from the WTSP from depths of 350-600 m (Benavides et al., 2015). Closely related cultivated isolates to the sequences found in this study include members of the Gammaproteobacterial genera Vibrio, Pseudomonas, Klebsiella and Agrobacterium. The cyanobacterium Pseudanabaena also had a relatively close relationship to the 650 dbar subcluster $1 \mathrm{G}$ sequences. When the proportion of sequences from subcluster $1 \mathrm{G}$ was low, members of cluster 3 , primarily subcluster 3S, tended to have higher relative abundances (mostly east of the Tonga Trench, located between stations SD9 and SD10; Fig. S1). The three major matches of sequences in this study for subcluster $3 \mathrm{~S}$ were sequences reported from the surface waters in the North Pacific Subtropical Gyre, the eastern North Atlantic and a hypersaline lake. The phylotype most commonly observed at 200 dbar was most similar to sequences reported in the tropical North Pacific (AAS98182). Cluster 3 is typically considered to contain obligate and facultative anaerobes including Spirochaeta and Desulfovibrio. Cluster 3 diazotrophs were present in low gene copy numbers in North Atlantic surface waters, even when $\mathrm{NO}_{3}^{-}$concentrations were high (Langlois et al., 2008). Members of cluster 3 have also been recovered in the mesopelagic WTSP (Benavides et al., 2015), although the present study reports longitudinal variation as a primary driver of cluster 3 phylotype diversity and relative abundance.
The cyanobacterial subcluster 1B including Trichodesmium, UCYN-A and Richelia was observed at a very low relative abundance throughout all stations and depths (average $0.5 \%$ of total community), in agreement with the findings of Caffin et al. (2017), who detected those phylotypes in sediment traps deployed during the OUTPACE cruise at 150 and $325 \mathrm{~m}$. Dead Trichodesmium colonies are thought to be mainly degraded in the photic zone (Letelier and Karl, 1998), although the detection of Trichodesmium in sediment traps and seawater samples obtained from the mesopelagic zone (Agustí et al., 2015; Chen et al., 2003; Pabortsava et al., 2017) suggests that decayed dense blooms likely sink fast down the water column. The detection of cyanobacterial diazotroph nifH sequences in the mesopelagic zone calls into question whether the $\mathrm{N}_{2}$ fixation rates measured are solely attributable to non-cyanobacterial diazotrophs (Moisander et al., 2017). Cyanobacterial photosynthetic diazotrophs reach the mesopelagic zone through sinking and sedimentation and thus are unlikely diazotrophically active when devoid of light. However, recent studies have detected photosynthetically active diatoms at depths overpassing the mesopelagic zone (Agustí et al., 2015), indicating that dead cell packages can be exported vertically at high speed. Whether cyanobacterial diazotrophs remain active when they reach the aphotic layer or whether they die or shut down $\mathrm{N}_{2}$ fixation on the way remains an open question.

The data presented here are a significant contribution to the scarce overall availability of aphotic $\mathrm{N}_{2}$ fixation rates, specifically the few available rates from the WTSP. Despite our limited knowledge of the ecophysiology of aphotic noncyanobacterial diazotrophs (Bombar et al., 2016), their ubiquity in the mesopelagic layer and the consistent detection of $\mathrm{N}_{2}$ fixation activity at all depths sampled during our study suggest that aphotic $\mathrm{N}_{2}$ fixation may contribute to fixed nitrogen input in this area.

Data availability. All data and metadata are available at the French INSU/CNRS LEFE CYBER database (scientific coordinator: Hervé Claustre; data manager and webmaster: Catherine Schmechtig) at the following web address: http://www.obs-vlfr.fr/proof/php/ outpace/outpace.php (INSU/CNRS LEFE CYBER, 2017).

Supplement. The supplement related to this article is available online at: https://doi.org/10.5194/bg-15-3107-2018-supplement.

Competing interests. The authors declare that they have no conflict of interest.

Special issue statement. This article is part of the special issue "Interactions between planktonic organisms and biogeochemical cycles across trophic and $\mathrm{N}_{2}$ fixation gradients in the western tropical 
South Pacific Ocean: a multidisciplinary approach (OUTPACE experiment)". It is not associated with a conference.

Acknowledgements. This is a contribution of the OUTPACE (Oligotrophy from Ultra-oligoTrophy PACific Experiment) project (https://outpace.mio.univ-amu.fr/, last access: May 2018) funded by the French research national agency (ANR-14-CE01-0007-01), the LEFE-CYBER program (CNRS-INSU), the GOPS program (IRD) and the CNES (BC T23, ZBC 4500048836). The OUTPACE cruise (https://doi.org/10.17600/15000900) was managed by MIO (OSU Institut Pythéas, AMU) from Marseilles (France). The authors thank the crew of the R/V L'Atalante for outstanding on-ship operations. Mar Benavides was funded by the People Programme (Marie Skłodowska-Curie Actions) of the European Union's Seventh Framework Programme (FP7/2007-2013) under REA grant agreement number 625185. The NSF OCE-1733610 award to Pia H. Moisander supported Pia H. Moisander and Katyanne M. Shoemaker. Solange Duhamel was funded by National Science Foundation award OCE-1434916 and by support from the Vetlesen Foundation.

Edited by: Douglas G. Capone

Reviewed by: Luisa I. Falcon and two anonymous referees

\section{References}

Agustí, S., González-Gordillo, J. I., Vaqué, D., Estrada, M., Cerezo, M. I., Salazar, G., Gasol, J. M., and Duarte, C. M.: Ubiquitous healthy diatoms in the deep sea confirm deep carbon injection by the biological pump, Nat. Commun., 6, 1-8, https://doi.org/10.1038/ncomms8608, 2015.

Benavides, M., H. Moisander, P., Berthelot, H., Dittmar, T., Grosso, O., and Bonnet, S.: Mesopelagic $\mathrm{N}_{2}$ fixation related to organic matter composition in the Solomon and Bismarck Seas (Southwest Pacific), PLOS ONE, 10, 1-19, https://doi.org/10.1371/journal.pone.0143775, 2015.

Benavides, M., Bonnet, S., Hernández, N., Martínez-Pérez, A. M., Nieto-Cid, M., Álvarez-Salgado, X. A., Baños, I., Montero, M. F., Mazuecos, I. P., Gasol, J. M., Osterholz, H., Dittmar, T., Berman-Frank, I., and Arístegui, J.: Basin-wide $\mathrm{N}_{2}$ fixation in the deep waters of the Mediterranean Sea, Global Biogeochem. Cy., 30, 1-19, https://doi.org/10.1002/2015GB005326, 2016.

Bentzon-Tilia, M., Severin, I., Hansen, L. H., and Riemann, L.: Genomics and Ecophysiology of Heterotrophic Nitrogen-Fixing Bacterial Isolated from Estuarine Surface Water, Am. Soc. Microbiol., 6, 1-11, https://doi.org/10.1128/mBio.00929-15, 2015.

Berthelot, H., Benavides, M., Moisander, P. H., Grosso, O., and Bonnet, S.: High-nitrogen fixation rates in the particulate and dissolved pools in the Western Tropical Pacific (Solomon and Bismarck Seas), Geophys. Res. Lett., 44, 8414-8423, https://doi.org/10.1002/2017GL073856, 2017.

Bombar, D., Paerl, R. W., and Riemann, L.: Marine Non-Cyanobacterial Diazotrophs: Moving beyond Molecular Detection, Trends Microbiol., 24, 916-927, https://doi.org/10.1016/j.tim.2016.07.002, 2016.

Bombar, D., Paerl, R. W., Anderson, R., and Riemann, L.: Filtration via Conventional Glass Fiber Filters in ${ }^{15} \mathrm{~N}_{2}$ Tracer Assays Fails to Capture All Nitrogen-Fixing Prokaryotes, Front. Mar. Sci., 5, https://doi.org/10.3389/fmars.2018.00006, 2018.

Bonnet, S., Biegala, I. C., Dutrieux, P., Slemons, L. O., and Capone, D. G.: Nitrogen fixation in the western equatorial Pacific: Rates, diazotrophic cyanobacterial size class distribution, and biogeochemical significance, Global Biogeochem. Cy., 23, 1-13, https://doi.org/10.1029/2008GB003439, 2009.

Bonnet, S., Dekaezemacker, J., Turk-Kubo, K. A., Moutin, T., Hamersley, R. M., Grosso, O., Zehr, J. P., and Capone, D. G.: Aphotic N2 fixation in the eastern tropical South Pacific Ocean, PLOS ONE, 8, 1-14, https://doi.org/10.1371/journal.pone.0081265, 2013.

Bonnet, S., Rodier, M., Turk-Kubo, K. A., Germineaud, C., Menkes, C., Ganachaud, A., Cravatte, S., Raimbault, P., Campbell, E., Quéroué, F., Sarthou, G., Desnues, A., Maes, C., and Eldin, G.: Contrasted geographical distribution of $\mathrm{N}_{2}$ fixation rates and nifH phylotypes in the Coral and Solomon Seas (southwestern Pacific) during austral winter conditions, Global Biogeochem. Cy., 29, 1874-1892, https://doi.org/10.1002/2015GB005117, 2015.

Bonnet, S., Caffin, M., Berthelot, H., and Moutin, T.: Hot spot of $\mathrm{N}_{2}$ fixation in the western tropical South Pacific pleads for a spatial decoupling between $\mathrm{N}_{2}$ fixation and denitrification, P. Natl. Acad. Sci. USA, 114(14), E2800-E2801, https://doi.org/10.1073/pnas.1619514114, 2017.

Bonnet, S., Caffin, M., Berthelot, H., Grosso, O., Benavides, M., Helias-Nunige, S., Guieu, C., Stenegren, M., and Foster, R. A.: In depth characterization of diazotroph activity across the Western Tropical South Pacific hot spot of $\mathrm{N}_{2}$ fixation, Biogeosciences Discuss., https://doi.org/10.5194/bg-2017-567, in review, 2018.

Caffin, M., Moutin, T., Foster, R. A., Bouruet-Aubertot, P., Doglioli, A. M., Berthelot, H., Grosso, O., Helias-Nunige, S., Leblond, N., Gimenez, A., Petrenko, A. A., de Verneil, A., and Bonnet, S.: Nitrogen budgets following a Lagrangian strategy in the Western Tropical South Pacific Ocean: the prominent role of $\mathrm{N}_{2}$ fixation (OUTPACE cruise), Biogeosciences Discuss., https://doi.org/10.5194/bg-2017-468, in review, 2017.

Caporaso, J. G., Kuczynski, J., Stombaugh, J., Bittinger, K., Bushman, F. D., Costello, E. K., Fierer, N., Peña, A. G., Goodrich, J. K., Gordon, J. I., Huttley, G. a, Kelley, S. T., Knights, D., Koenig, J. E., Ley, R. E., Lozupone, C. a, Mcdonald, D., Muegge, B. D., Pirrung, M., Reeder, J., Sevinsky, J. R., Turnbaugh, P. J., Walters, W. a, Widmann, J., Yatsunenko, T., Zaneveld, J., and Knight, R.: correspondence QIIME allows analysis of high- throughput community sequencing data Intensity normalization improves color calling in SOLiD sequencing, Nat. Publ. Gr., 7, 335-336, https://doi.org/10.1038/nmeth.f.303, 2010.

Chen, Y. L. L., Chen, H. Y., and Lin, Y. H.: Distribution and downward flux of Trichodesmium in the South China Sea as influenced by the transport from the Kuroshio Current, Mar. Ecol. Prog. Ser., 259, 47-57, https://doi.org/10.3354/meps259047, 2003.

Chien, Y.-T. and Zinder, S. H.: Cloning, functional organization, transcript studies, and phylogenetic analysis of the complete nitrogenase structural genes (nifHDK2) and associated genes in the archaeon Methanosarcina barkeri 227, J. Bacteriol., 178, 143148, 1996.

Codispoti, L. A.: An oceanic fixed nitrogen sink exceeding $400 \mathrm{Tg} \mathrm{Na}^{-1}$ vs the concept of homeostasis in the 
fixed-nitrogen inventory, Biogeosciences, 4, 233-253, https://doi.org/10.5194/bg-4-233-2007, 2007.

de Verneil, A., Rousselet, L., Doglioli, A. M., Petrenko, A. A., and Moutin, T.: The fate of a southwest Pacific bloom: gauging the impact of submesoscale vs. mesoscale circulation on biological gradients in the subtropics, Biogeosciences, 14, 3471-3486, https://doi.org/10.5194/bg-14-3471-2017, 2017.

Dittmar, T., Koch, B., Hertkorn, N., and Kattner, G.: A simple and efficient method for the solid-phase extraction of dissolved organic matter (SPE-DOM) from seawater, Limnol. Oceanogr.Meth., 6, 230-235, https://doi.org/10.4319/lom.2008.6.230, 2008.

Edgar, R. C.: Search and clustering orders of magnitude faster than BLAST, Bioinformatics, 26, 2460-2461, https://doi.org/10.1093/bioinformatics/btq461, 2010.

Farnelid, H., Andersson, A. F., Bertilsson, S., Al-Soud, W. A., Hansen, L. H., Sørensen, S., Steward, G. F., Hagström, ̊̊., and Riemann, L.: Nitrogenase gene amplicons from global marine surface waters are dominated by genes of non-cyanobacteria, PLOS ONE, 6, e19223, https://doi.org/10.1371/journal.pone.0019223, 2011.

Fernandez, C., Farías, L., and Ulloa, O.: Nitrogen fixation in denitrified marine waters, PLoS One, 6, e19223, https://doi.org/10.1371/journal.pone.0020539, 2011.

Frank, I. E., Turk-Kubo, K. A., and Zehr, J. P.: Rapid annotation of nifH gene sequences using classification and regression trees facilitates environmental functional gene analysis, Environ. Microbiol. Rep., 8, 905-916, https://doi.org/10.1111/17582229.12455, 2016.

Fumenia, A., Moutin, T., Bonnet, S., Benavides, M., Petrenko, A., Helias Nunige, S., and Maes, C.: Excess nitrogen as a marker of intense dinitrogen fixation in the Western Tropical South Pacific Ocean: impact on the thermocline waters of the South Pacific, Biogeosciences Discuss., https://doi.org/10.5194/bg-2017557, in review, 2018.

Galloway, J. N., Dentener, F. J., Capone, D. G., Boyer, E. W., Howarth, R. W., Seitzinger, S. P., Asner, G. P., Cleveland, C. C., Green, P. A., Holland, E. A., Karl, D. M., Michaels, A. F., Porter, J. H., Townsend, A. R., and Vo, C. J.: Nitrogen cycles: past, present, and future, Biogeochemistry, 70, 53-226, 2004.

Gruber, N. and Galloway, J. N.: An Earth-system perspective of the global nitrogen cycle, Nature, 451, 293-296, https://doi.org/10.1038/nature06592, 2008.

Halm, H., Lam, P., Ferdelman, T. G., Lavik, G., Dittmar, T., Laroche, J., D'Hondt, S., and Kuypers, M. M. M.: Heterotrophic organisms dominate nitrogen fixation in the south pacific gyre, ISME J., 6, 1238-1249, https://doi.org/10.1038/ismej.2011.182, 2011.

Hamersley, M. R., Turk, K. A., Leinweber, A., Gruber, N., Zehr, J. P., Gunderson, T., and Capone, D. G.: Nitrogen fixation within the water column associated with two hypoxic basins in the Southern California Bight, Aquat. Microb. Ecol., 63, 193-205, https://doi.org/10.3354/ame01494, 2011.

Herbland, A., Le Bouteiller, A., and Raimbault, P.: Size structure of phytoplankton biomass in the equatorial Atlantic Ocean, Deep-Sea Res., 32, 819-836, https://doi.org/10.1016/j.dsr2.2013.07.011, 1985.

Hewson, I., Moisander, P. H., Achilles, K. M., Carlson, C. A., Jenkins, B. D., Mondragon, E. A., Morrison, A. E., and Zehr,
J. P.: Characteristics of diazotrophs in surface to abyssopelagic waters of the Sargasso Sea, Aquat. Microb. Ecol., 46, 15-30, https://doi.org/10.3354/ame046015, 2007.

INSU/CNRS LEFE CYBER: OUTPACE (Oligotrophy to UITraoligotrophy PACific Experiment), available at: http://www. obs-vlfr.fr/proof/php/outpace/outpace.php (last access: 8 May 2018), 2017.

Jayakumar, A., Al-Rshaidat, M. M. D., Ward, B. B., and Mulholland, M. R.: Diversity, distribution, and expression of diazotroph nifH genes in oxygen-deficient waters of the Arabian Sea, FEMS Microbiol. Ecol., 82, 597-606, https://doi.org/10.1111/j.15746941.2012.01430.x, 2012.

Jickells, T. D., Buitenhuis, E., Altieri, K., Baker, A. R., Capone, D., Duce, R. A., Dentener, F., Fennel, K., Kanakidou, M., LaRoche, J., Lee, K., Liss, P., Middelburg, J. J., Moore, J. K., Okin, G., Oschlies, A., Sarin, M., Seitzinger, S., Sharples, J., Singh, A., Suntharalingam, P., Uematsu, M., and Zamora, L. M.: A reevaluation of the magnitude and impacts of anthropogenic atmospheric nitrogen inputs on the ocean, Global Biogeochem. Cy., 31, 289305, https://doi.org/10.1002/2016GB005586, 2017.

Kana, T. M., Darkangelo, C., Hunt, M. D., Oldham, J. B., Bennett, G. E., and Cornwell, J. C.: Membrane lnlet Mass Spectrometer for Rapid Environmental Water Samples, Anal. Chem., 66, 4166-4170, 1994.

Koch, B. P. and Dittmar, T.: From mass to structure: An aromaticity index for high-resolution mass data of natural organic matter, Rapid Commun. Mass Sp., 20, 926-932, https://doi.org/10.1002/rcm.2386, 2006.

Langlois, R., Großkopf, T., Mills, M., Takeda, S. and LaRoche, J.: Widespread distribution and expression of Gamma A (UMB), an uncultured, diazotrophic, $\gamma$ proteobacterial nifH phylotype, PLOS ONE, 10, 1-17, https://doi.org/10.1371/journal.pone.0128912, 2015.

Langlois, R. J., Hümmer, D., and LaRoche, J.: Abundances and distributions of the dominant nifH phylotypes in the Northern Atlantic Ocean, Appl. Environ. Microb., 74, 1922-1931, https://doi.org/10.1128/AEM.01720-07, 2008.

Letelier, R. M. and Karl, D. M.: Trichodesmium spp. physiology and nutrient fluxes in the North Pacific subtronical gyre, Aquat Microb. Ecol., 15, 265-276, https://doi.org/10.3354/ame015265, 1998.

Loescher, C. R., Großkopf, T., Desai, F. D., Gill, D., Schunck, H., Croot, P. L., Schlosser, C., Neulinger, S. C., Pinnow, N., Lavik, G., Kuypers, M. M. M., Laroche, J., and Schmitz, R. A.: Facets of diazotrophy in the oxygen minimum zone waters off Peru, ISME J., 8, 2180-2192, https://doi.org/10.1038/ismej.2014.71, 2014.

Ludwig, W., Strunk, O., Westram, R., Richter, L., Meier, H., Yadhukumar, A., Buchner, A., Lai, T., Steppi, S., Jacob, G., Förster, W., Brettske, I., Gerber, S., Ginhart, A. W., Gross, O., Grumann, S., Hermann, S., Jost, R., König, A., Liss, T., Lüßbmann, R., May, M., Nonhoff, B., Reichel, B., Strehlow, R., Stamatakis, A., Stuckmann, N., Vilbig, A., Lenke, M., Ludwig, T., Bode, A., and Schleifer, K. H.: ARB: A software environment for sequence data, Nucleic Acids Res., 32, 1363-1371, https://doi.org/10.1093/nar/gkh293, 2004.

Messer, L. F., Brown, M. V., Furnas, M. J., Carney, R. L., McKinnon, A. D., and Seymour, J. R.: Diversity and activity of diazotrophs in great barrier reef surface waters, Front. Microbiol., 8, 1-16, https://doi.org/10.3389/fmicb.2017.00967, 2017. 
Moisander, P. H., Beinart, R. A., Voss, M., and Zehr, J. P.: Diversity and abundance of diazotrophic microorganisms in the South China Sea during intermonsoon, ISME J., 2, 954-967, https://doi.org/10.1038/ismej.2008.51, 2008.

Moisander, P. H., Beinart, R. A., Hewson, I., White, A. E., Johnson, K. S., Carlson, C. A., Montoya, J. P., and Zehr, J. P.: Unicellular cyanobacterial distributions broaden the oceanic $\mathrm{N}_{2}$ fixation domain, Science, 327, 1512-1514, https://doi.org/10.1126/science.1185468, 2010.

Moisander, P. H., Serros, T., Paerl, R. W., Beinart, R. A., and Zehr, J. P.: Gammaproteobacterial diazotrophs and nifH gene expression in surface waters of the South Pacific Ocean, ISME J., 8, 1962 1973, https://doi.org/10.1038/ismej.2014.49, 2014.

Moisander, P. H., Benavides, M., Bonnet, S., Berman-Frank, I., White, A. E., and Riemann, L.: Chasing after non-cyanobacterial nitrogen fixation in marine pelagic environments, Front. Microbiol., 8, 1736, https://doi.org/10.3389/fmicb.2017.01736, 2017.

Montoya, J. P., Voss, M., Kahler, P. and Capone, D. G.: A Simple, High-Precision, High-Sensitivity Tracer Assay for $\mathrm{N}_{2}$ Fixation, Appl. Environ. Microb., 62, 986-993, 1996.

Moutin, T., Doglioli, A. M., de Verneil, A., and Bonnet, S.: Preface: The Oligotrophy to the UlTra-oligotrophy PACific Experiment (OUTPACE cruise, 18 February to 3 April 2015), Biogeosciences, 14, 3207-3220, https://doi.org/10.5194/bg-143207-2017, 2017.

Oksanen, J., Blanchet, G., Klindt, R., Legendre, P., Minchin, P. R., O'Hara, R. B., Simpson, G. L., Solymos, P., Stevens, M. H. H., and Wagner, H.: Vegan: Community ecology package, R package version 2.3-4, available at: http://CRAN.R-project.org/package= vegan (last access: 15 September 2017), 2015.

Pabortsava, K., Lampitt, R. S., Benson, J., Crowe, C., McLachlan, R., Le Moigne, F. A. C., Mark Moore, C., Pebody, C., Provost, P., Rees, A. P., Tilstone, G. H. and Woodward, E. M. S.: Carbon sequestration in the deep Atlantic enhanced by Saharan dust, Nat. Geosci., 10, 189-194, https://doi.org/10.1038/ngeo2899, 2017.

Rahav, E., Bar-Zeev, E., Ohayon, S., Elifantz, H., Belkin, N., Herut, B., Mulholland, M. R., and Berman-Frank, I.: Dinitrogen fixation in aphotic oxygenated marine environments, Front. Microbiol., 4, 1-11, https://doi.org/10.3389/fmicb.2013.00227, 2013.

Raimbault, P. and Garcia, N.: Evidence for efficient regenerated production and dinitrogen fixation in nitrogen-deficient waters of the South Pacific Ocean: impact on new and export production estimates, Biogeosciences, 5, 323-338, https://doi.org/10.5194/bg-5-323-2008, 2008.
Riemann, L., Farnelid, H., and Steward, G. F.: Nitrogenase genes in non-cyanobacterial plankton: Prevalence, diversity and regulation in marine waters, Aquat. Microb. Ecol., 61, 235-247, https://doi.org/10.3354/ame01431, 2010.

Schloss, P. D., Westcott, S. L., Ryabin, T., Hall, J. R., Hartmann, M., Hollister, E. B., Lesniewski, R. A., Oakley, B. B., Parks, D. H., Robinson, C. J., Sahl, J. W., Stres, B., Thallinger, G. G., Van Horn, D. J. and Weber, C. F.: Introducing mothur: Open-source, platform-independent, community-supported software for describing and comparing microbial communities, Appl. Environ. Microb., 75, 7537-7541, https://doi.org/10.1128/AEM.0154109, 2009.

Seidel, M., Beck, M., Riedel, T., Waska, H., Suryaputra, I. G. N. A., Schnetger, B., Niggemann, J., Simon, M., and Dittmar, T.: Biogeochemistry of dissolved organic matter in an anoxic intertidal creek bank, Geochim. Cosmochim. Ac., 140, 418-434, https://doi.org/10.1016/j.gca.2014.05.038, 2014.

Severin, I., Bentzon-tilia, M., Moisander, P. H., and Riemann, L.: Nitrogenase expression in estuarine bacterioplankton influenced by organic carbon and availability of oxygen, FEMS Microbiol. Lett., 362, 1-26, 2015.

Sohrin, R. and Sempéré, R.: Seasonal variation in total organic carbon in the northeast Atlantic in 2000-2001, J. Geophys. Res., 110, C10S90, https://doi.org/10.1029/2004JC002731, 2005.

Stenegren, M., Caputo, A., Berg, C., Bonnet, S., and Foster, R. A.: Distribution and drivers of symbiotic and free-living diazotrophic cyanobacteria in the western tropical South Pacific, Biogeosciences, 15, 1559-1578, https://doi.org/10.5194/bg-151559-2018, 2018.

Steward, G. F., Jenkins, B. D., Ward, B. B., and Zehr, J. P.: Development and testing of a DNA macroarray to assess nitrogenase (nifH) gene diversity, Appl. Environ. Microb., 70, 1455-1465, 2004.

Turk, K. A., Rees, A. P., Zehr, J. P., Pereira, N., Swift, P., Shelley, R., Lohan, M., Woodward, E. M. S., and Gilbert, J.: Nitrogen fixation and nitrogenase (nifH) expression in tropical waters of the eastern North Atlantic, ISME J., 5, 1201-1212, https://doi.org/10.1038/ismej.2010.205, 2011.

Zehr, J., Waterbury, J., and Turner, P.: Unicellular cyanobacteria fix $\mathrm{N}_{2}$ in the subtropical North Pacific Ocean, Nature, 715, 25-28, https://doi.org/10.1038/news010809-11, 2001.

Zehr, J. P.: Nitrogen fixation by marine cyanobacteria, Trends Microbiol., 19, 162-173, https://doi.org/10.1016/j.tim.2010.12.004, 2011. 